\title{
Protection issues of Power Systems with PV Systems Based Distributed Generation
}

\author{
Puladasu sudhakar ${ }^{1}$, Dr.Sushama Malaji ${ }^{2}$ Dr.B.Sarvesh ${ }^{3}$ \\ ${ }^{I}$ (Research scholar at JNTUA/ JNTUniversity, India) \\ ${ }^{2}$ (Professor and supervisor at JNTUH/ JNTUniversity, India) \\ ${ }^{3}$ (Senior Professor and co-supervisor at JNTUA/ JNTUniversity, India)
}

\begin{abstract}
The main purpose of this paper is to discuss the basic understanding of active and reactive power flows in photovoltaic $(P V)$ based distributed generation injected power system and how these power flows will influence the performance and stability of a power system. the harmonic currents injected into the utility grid may be a serious problem since they could lead to unacceptable levels of wave shapes distortion, power reversals and voltage regulation The proposed technology is to inject scheduled amount of real and reactive powers in to the grid while maintaining the balance between input and output powers, to protect the power system against the voltage fluctuations, voltage imbalance, power reversals, high short circuit current, harmonic distortion. A grid connected photovoltaic system is modeled and simulated using Matlab/Simulink.
\end{abstract}

Keyword: Active power Distributed Generation, Photovoltaic System protection issues, Reactive power

\section{Introduction}

Many DG's are connected to the grid via power converters, which injects harmonics into the system. the connection of DG might cause over-voltage, fluctuation and unbalance of the system voltage if coordination with the utility supply is not properly achieved. Depending on the network configuration, the penetration level and the nature of the DG technology, the power injection of DG may increase the power losses in the distribution system. Short circuit levels are changed when a DG is connected to the network. Therefore, relay settings should be changed and if there is a disconnection of DG, relay should be changed back to its previous state.

Photovoltaic cells convert solar radiation directly into DC electrical energy. The basic material for almost all the photovoltaic cells existing in the market, which is high purified silicon ( $\mathrm{Si}$ ), is obtained from sand or quartz. Basically, three types of technology are used in the production of photovoltaic cells: mono-crystalline; polycrystalline; and amorphous silicon. The crystalline-Si technology is commonly used as a reference, or baseline, for the solar power generation technology. In general, the status of a photovoltaic cell technology depends on the cell efficiency, and manufacturing cost. The focus of R\&D all over the world is on improving its efficiency and cost, where the optimal solution is based on a trade-off between the two. The efficiency of a photovoltaic cell is determined by the material's ability to absorb photon energy over a wide range, and on the band gap of the material. Photovoltaic cells are semiconductors that have weakly bonded electrons at a level of energy called valence band. When energy strikes this valence band, it frees those bonded electrons and moves them to another energy level called conduction band. At the conduction band, the electrons are able to conduct electricity through an electrical load. PV cells use the energy of photons from sunlight to break their band gap energy thereby producing DC current. Typically, PV cells produce low power (approximately 2-3Watts); hence several cells are connected together to form modules and panels for higher power applications. Power regulation elements (e.g. battery, charge controller, converter, etc....) mare also incorporated to match the output power form to the demanded application. Figure 1 shows the simple concept of photovoltaic system.

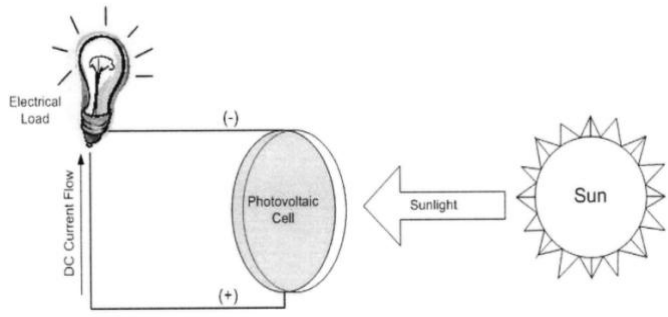

Fig2.1Concept of photovoltaic Crystalline and polycrystalline silicon's are the materials most commonly used in photovoltaic cells. The advantage of silicon cells is primarily the abundance of silicon on earth. The photovoltaic cell consists of several layers of semiconductor materials with different electronic properties .In a typical polycrystalline cell, the bulk of the material is silicon, doped with a small quantity of boron to give it a 
positive or p-type character. A thin layer on the front of the cell is doped with phosphorous to give it a negative or n-type character The interface between these two layers produces an electric field and forms the so-called a "cell junction". When the cell is exposed to sunlight, a certain percentage of the incoming photons are absorbed in the region of the junction, freeing electrons in the silicon crystal. If the photons have enough energy, the electrons will be able to overcome the electric field at the junction and are free to move through the silicon and into an external circuit. The Direction of the electric current is opposite to its direction if the device operates as a diode.

\subsubsection{Photovoltaic cell:}

\section{Analysis Of Photovoltaic Systems}

PV cell are basically semiconductor diode. This semiconductor diode has got a p-n junction which is exposed to light. When illuminated by sunlight it generates electric power. PV cell are made up of various semiconductor materials. But mono-crystalline silicon and poly-crystalline silicon are mainly used for commercial use.

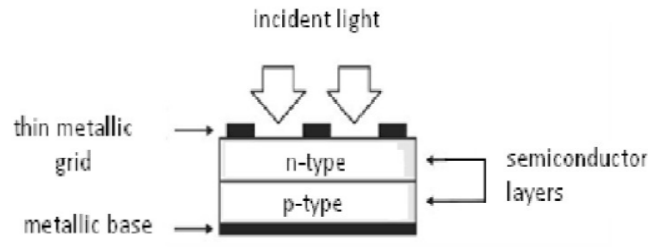

Figure.2.1: Basic PV cell structure

\subsubsection{Photovoltaic module:}

The power produced by a single PV cell is not enough for general use. So by connecting many single PV cell in series (for high voltage requirement) and in parallel (for high current requirement) can get us the desired power. Generally a series connection is chosen this set of arrangement is known as a module. Generally commercial modules consist of 36 or 72 cells. The modules consist of transparent front side, encapsulated PV cell and back side. The front side material is usually made up of low-iron and tempered glass. The efficiency of a PV module is less than a PV cell. This is due to the fact that some radiation is reflected by the glass cover and frame shadowing etc.

\subsubsection{Photovoltaic Array:}

A photovoltaic array (PV system) is a interconnection of modules which in turn is made up of many PV cells in series or parallel. The power produced by a single module is seldom enough for commercial use, so modules are connected to form array to supply the load. The connection of the modules in an array is same as that of cells in a module. Modules can also be connected in series to get an increased voltage or in parallel to get an increased current. In urban uses, generally the arrays are mounted on a rooftop. In agricultural use, the output of an array can directly feed a DC motor.

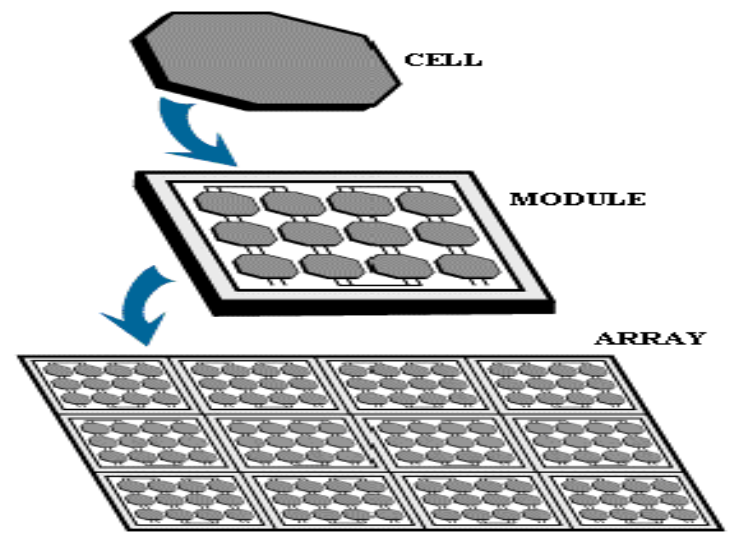

Figure2.2: Photovoltaic Hierarchy 


\subsubsection{Working of PV cell:}

Working of a PV cell is based on the basic principle of photoelectric effect. Photoelectric effect can be defined as a phenomenon in which an electron gets ejected from the conduction band as a consequence of the absorption of sunlight of a certain wavelength by the matter (metallic or non-metallic solids, liquids or gases).So, in a photovoltaic cell, when sunlight strikes its surface, some portion of the solar energy is absorbed in the semiconductor material. If absorbed energy is greater than the band gap energy of the semiconductor, the electron from valence band jumps to the conduction band. By this, pairs of hole-electrons are created in the illuminated region of the semiconductor. The electrons thus created in the conduction band are now free to move. These free electrons are forced to move in a particular

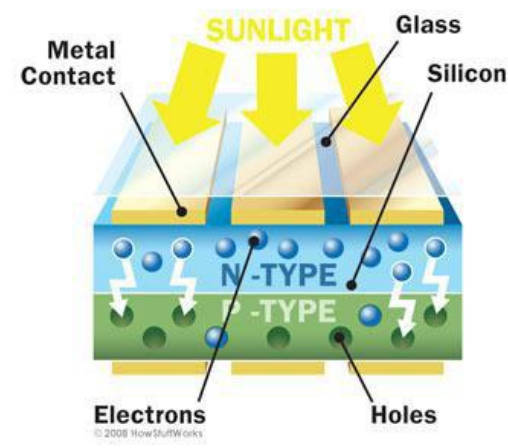

Figure2.3: Working of PV cell

Direction by the action of electric field presents in the PV cells. These flowing electrons constitutes current and can be drawn for external use by connecting a metal plate on top and bottom of PV cell. This current and the voltage (created because of its built-in electric fields) produces required power.

\subsubsection{Characteristics of a PV cell:}

In a PV characteristic there are basically three important points viz. open circuit voltage(Vo), short circuit current (Isc) and maximum power point (MPPT ). The maximum power that can be extracted from a PV cell are at the maximum power points. Usually manufacturers provide these parameters in their datasheets for a particular PV cell or module. By using these parameters we can build a simple model but for more information is required for designing an accurate model.

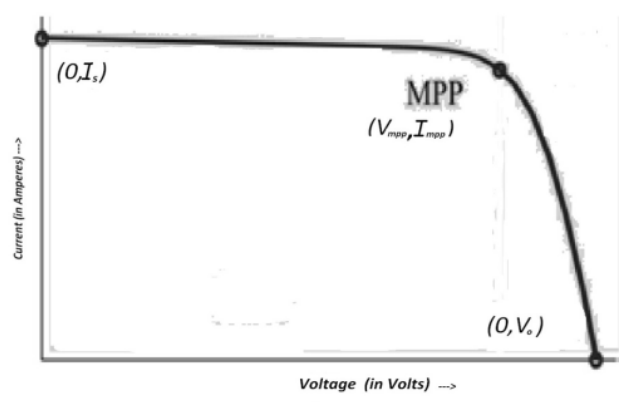

Figure2.4: characteristics of a PV cell

The characteristic Equation for the $\mathrm{PV}$ cell is given by:

\section{$\mathbf{I}=\mathbf{I}_{\mathrm{ph}}-\mathbf{I}_{\mathrm{os}}\left[\exp \left(\mathbf{v}+\mathbf{R}_{\mathrm{se}} \mathbf{I}\right) /\left(\mathbf{V}_{\mathrm{t}} \mathbf{a}\right)-\mathbf{1}\right]-\left(\mathbf{v}+\mathbf{R}_{\mathrm{se}} \mathbf{I}\right) /\left(\mathbf{V}_{\mathrm{t}} \mathbf{a}\right)$}

Where

$\mathbf{I}_{\mathbf{p h}}$-Light-generated Current or Photocurrent: It is generated directly by incident of sunlight on the PV cell. This current varies linearly with sun irradiation and depends on temperature given by :

$\mathbf{I}_{\mathrm{ph}}=\left(\mathbf{I}_{\mathrm{ph}, \mathbf{n}}+\mathbf{K i} \Delta \mathbf{T}\right) \mathbf{G} / \mathbf{G}_{\mathbf{n}}$

where, $\mathbf{I}_{\mathbf{p h}, \mathbf{n}}=$ Light-generated current at nominal condition

$\mathrm{Ki}=$ Current temperature co-efficient (in)

$\mathbf{G}=$ Actual sun irradiation (in )

$\mathbf{G}_{\mathbf{n}}=$ Nominal sun irradiation

$\Delta \mathbf{T}=\mathrm{It}$ is the difference between actual temperature and nominal temperature(in Kelvin i.e.,T-Tn ) 
$\mathbf{I}_{\text {os }}$ - Diode Saturation Current: It is a part of the reverse current in a diode caused by diffusion of minority carriers from the neutral regions to the depletion region.

$\mathbf{R}_{\mathrm{se}} \& \mathbf{R}_{\mathrm{pa}}-$ Due to the presence of internal resistances, the power loss takes place in the cell. These parasitic resistances can be segregated into series resistance, $\mathbf{R}_{\mathrm{se}}$ and parallel resistance . $\mathbf{R}_{\mathrm{pa}}$ For ideal case, $\mathbf{R}_{\mathrm{se}}$ would be „zero" and $\mathbf{R}_{\mathrm{pa}}$ would be ,infinity".

a- Diode ideality factor: It is the measure of how much a practical diode deviates from ideal diode equation. The average value assumed during the determination of unknown parameters in the photovoltaic system is usually , $1.3^{\text {ec }}$.

$\mathbf{V}_{\mathrm{T}}$ - Junction thermal voltage: It is a characteristic voltage that relates current flow in the p-n junction to the electrostatic potential across it.

Where,

$$
\mathbf{V}_{\mathrm{T}}=\mathrm{kT} / \mathrm{q} \text {; }
$$

$\mathbf{K}=$ Boltzmann constant $=1.3806503 \times \mathrm{J} / \mathrm{K}$

$\mathbf{q}=$ electron charge $=1.607 \mathrm{C}$

$\mathbf{T}=$ Nominal Temperature $=298.15 \mathrm{~K}$

\section{Photovoltaic Systems Modeling}

The typical structure of a grid connected PV unit is shown in Figure 6. Its main components are the PV array, the DC/DC, DC/AC converters and the associated (converter and overall system) controls. A storage device is absent in large grid-connected installations (except maybe for small critical loads).

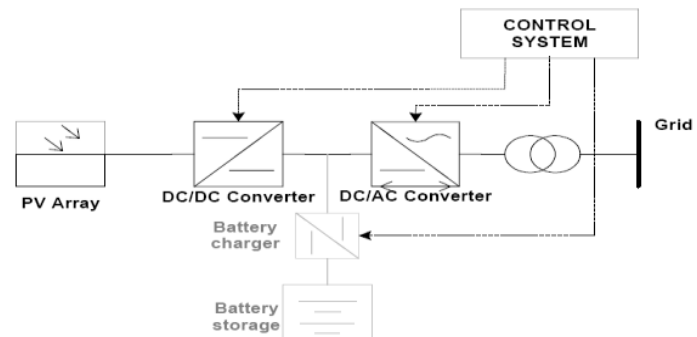

Figure 3.1: Typical Structure of a Grid Connected PV Generator

In Figure 3.6 the series resistance Rs represents the internal losses due to the current flow, whereas the shunt resistance Rsh corresponds to the leakage current to the ground and it is normally ignored. In an ideal cell $\mathrm{Rs}=\mathrm{Rsh}=0$, which is a common assumption. The equivalent circuit of a PV module, which consists of a combination of series and parallel connected cells, are the same.

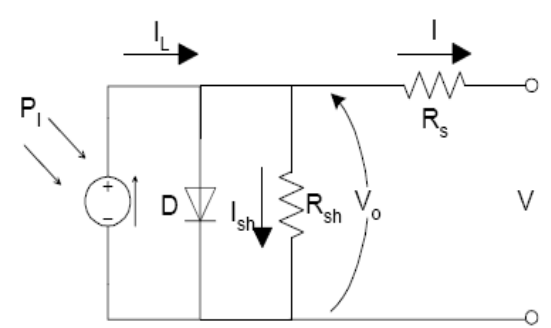

Figure 3.2: PV Cell Equivalent Circuit

The governing equations of the equivalent circuit are:

$$
\begin{aligned}
& V=V_{0}-R_{S} I \\
& I=I_{L}-I_{D}\left(e^{(\mathrm{qV0} / A K T)}-1\right)-I_{\text {sh }} \\
& I_{\text {sh }}=V_{0} / R_{\text {sh }} \\
& I_{I}=I_{\text {scl }}\left(P_{1 / 1000}\right)
\end{aligned}
$$

Where:

$\mathrm{V}, \mathrm{I}$ - output voltage and current 
$\mathrm{q}$ - Electron charge $(1.6 * 10-19 \mathrm{Cb})$

$\mathrm{k}-$ Boltzmann constant $(1.38 * 10-23 \mathrm{~J} / \mathrm{K})$

$\mathrm{T}$ - Temperature in $\mathrm{K}$

A - Quality factor (constant)

$\mathrm{I}_{\mathrm{D}}-$ reverse saturation current of the diode

$\mathrm{I}_{\mathrm{L}}$ - photocurrent, dependent on $\mathrm{T}$

$\mathrm{P}_{\mathrm{I}}$ - insolation level in $\mathrm{W} / \mathrm{m} 2$

$\mathrm{I}_{\mathrm{sc} 1}-$ short circuit current at $1000 \mathrm{~W} / \mathrm{m} 2$ solar radiation

Multiple PV modules are connected in series and in parallel to form the PV array. Similar equations hold for the whole array, provided that all modules are identical and subject to the same isolation. In Error! Reference source not found. the V-I characteristics of a $250 \mathrm{Kw}$ array are shown at three solar radiation (PI) levels. On the same diagram three constant power curves (red lines) have been drawn. It is clear that, for a given isolation, the array produces maximum power only when operating near the knee point of the corresponding V-I curve (maximum power point). The task of tracking the maximum power point (MPPT) is usually performed by a DC/DC converter at the output of the array, which regulates the voltage to the desired value. Since no moving parts are employed in this process, the response of the MPPT can be considered instantaneous for system studies.

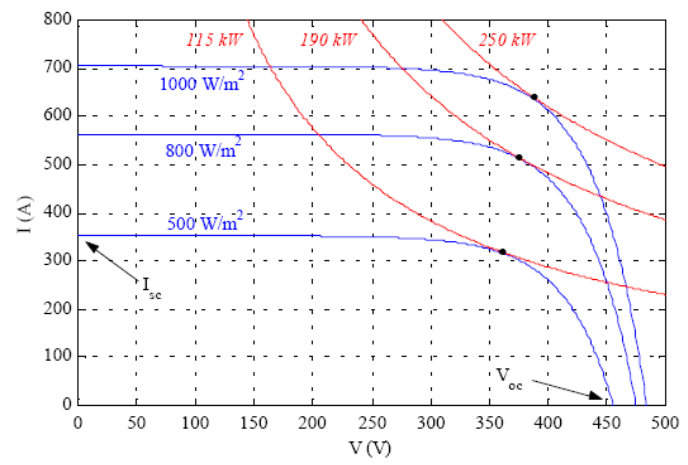

Figure 3.3: Typical PV array V-I characteristics

A device that may affect the response of the PV generator output in case of solar radiation changes is the sun-tracking system of the panels, which adjusts the orientation of the panels with respect to the sun, a task performed by the use of properly controlled servomotors. However, these are relatively slow acting devices and may be ignored in transient stability studies. As discussed, the remaining system components (dc bus, inverter and grid-connection devices) are of similar nature and characteristics as for other dispersed generators (e.g. variable speed wind turbines) as are the modeling requirements.

\section{Photovoltaic Systems Grid Integration Issues}

Fault currents for grid connected and islanded operation of micro grid are different. The short circuit power varies significantly. Faults also causes loss of sensitivity, over current, earth leakage, disconnection of generators, islanding, reducing reach of over current relays, single phase connections and loss of stability .Depending upon location of faults with respect to distributed generators and existing protection equipment, problems like bidirectional power flow and change in voltage profile occurs. The power output of distributed generators like synchronous generators, whenever there is a fault, power output of these DG sources changes. Modification in fault current level, device discrimination, reduction in reach of impedance relays, reverse power flow, sympathetic tripping, islanding, single phase connection, selectivity are the key protection issues.

\subsubsection{Modification in fault current level}

When large number of small distributed generation units that uses synchronous or induction generator units are connected to distribution network or grid it changes fault current level as both types of generators contribute towards fault currents. When inverter interfaced DG units are used, fault current is limited to a lower value. As fault current is not high as compared to load current, some of the relays do not trip, others that respond to fault operate with the time delay. The undetected fault spreads out in the system and can damage the equipment. Fault impedance also decreases when DG is connected into network in parallel with the other devices. When faults occurs downstream of the point of common coupling, both the main source and DG contributes fault current. Relay placed at upstream of DG measure fault current supplied by upstream source. In 
Fig. 1 the relay placed at the upstream of DG measure the fault current supplied by upstream source. Actual fault current is different, relays will not function properly and there will be coordination problems. If there is short circuit fault, when DG is integrated with the main grid it will affect the amplitude, direction and duration of fault currents.

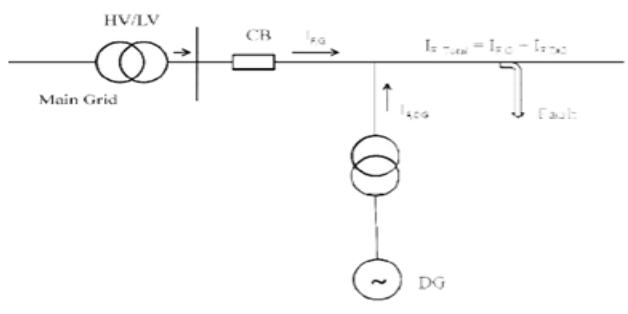

\section{Fig.1. Fault Current contribution from DG and Grid}

\subsubsection{Device discrimination}

In the power system network that has generation sources at the end of network, fault current decreases with increase in distance as the impedance increases. The variation in magnitude of fault current is used for discrimination. In case of islanded micro grid with inverter interfaced distributed generation units, fault is limited to a lower value, fault level at the locations of feeder will be almost constant .The traditional current protection scheme which uses the variation in magnitude of fault current for discrimination does not work properly. New protection system for device protection is required.

\subsubsection{Reduction in reach of Impedance relays}

The reach of impedance relay depends upon the distance between the relay location and fault point, maximum distance means minimum fault current that is detected. When DG is according to defined zone settings. When faults occurs downstream of the bus DG connected to utility network, impedance measured by relay located in upstream is higher than real fault impedance. This affects grading of relays and causes delayed operation or sometimes relay does not operate at all.

\subsubsection{Reverse Power flow}

Main challenge for protecting the micro grid arises because power can flow in both the directions in each feeder of micro grid. Sources are located in both sides of load due to which power flows in opposite direction from two sources towards the load. Power flow also changes its direction in case of distribution network with embedded generation when local generation exceeds local consumption. The reverse power flow can also cause power quality problems resulting in variation of voltage.

\subsubsection{Sympathetic Tripping}

This occurs when protective device operates for faults in an outside protective zone. DG contributes towards the fault; relay operates along with another relay which actually sees the fault resulting in malfunctioning of protective scheme. Relay on line 2 will unnecessarily operate for fault F1 at line L1 as a result of in feed from DG to fault current as shown in Fig.2

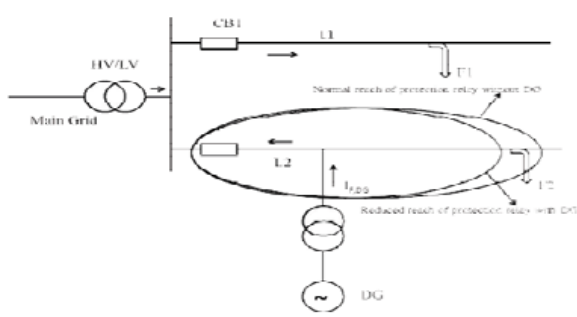

Fig.2.Uderreaching of relay and sympathetic tripping due to DG connection

\subsubsection{Islanding}

The DG creates a problem when part of distributed network with DG unit is islanded. Islanding is due to fault in the network. If generator continues to supply power despite the disconnection of utility, fault might 
persist as fault is fed by DG . If the control for the voltage is not provided, it results in unexpected rise in voltage levels in case of islanded operation.

\subsubsection{Single phase connection}

Some DG sources inject single phase power into the distribution grid, for example PV systems. This affects balance of three phase currents, due to unbalance current in the neutral conductor increases which also results in flow of stray currents to earth. This current should be limited to prevent overloading.

\subsubsection{Selectivity}

Protection system is said to be selective if the protection device closest to the fault operates to remove the faulty Section. Without DG, there is power flow in only one direction, during normal operation as well as when there is fault, by using time graded over current relays selectivity can be obtained.When DG is integrated with the grid ,this systems becomes inadequate. There is possibility of disconnection of healthy feeder by its own protective relay because it contributes to the short circuit current flowing through fault in the neighboring feeder. The tripping current for electrical protective device is between maximum load current and minimum fault current. Fault current and load current depends upon the state of grid, state of distributed generators and whether micro grid is operating in islanded mode. The main challenge for protecting the micro grid arises from the fact that power can flow in both the directions in each feeder of the micro grid. Close to each local load, there may exist two or more sources that contribute to the loaded power. The sources are located in both sides of load due to which power flows in opposite direction from two sources towards the load

\section{Simulation Results Of A Pv System}

The simulation of a solar cell was done using MATLAB and SIMULINK. The PV and IV curves from the simulation are as shown.

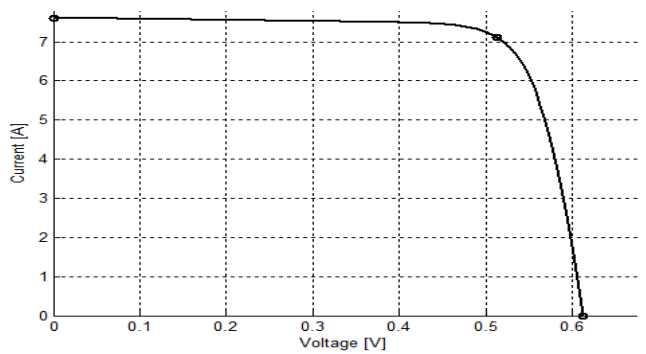

Figure 5.1: I-V characteristics of a solar cell

The parameters were obtained for a generalized solar cell. The plot is similar to the theoretically known plot of the solar cell voltage and current. The peak power is denoted by a circle in the plot. Since only one solar cell in series is considered, hence the solar output voltage is less $(0.61 \mathrm{~V})$ in this case. The

\subsection{Results}

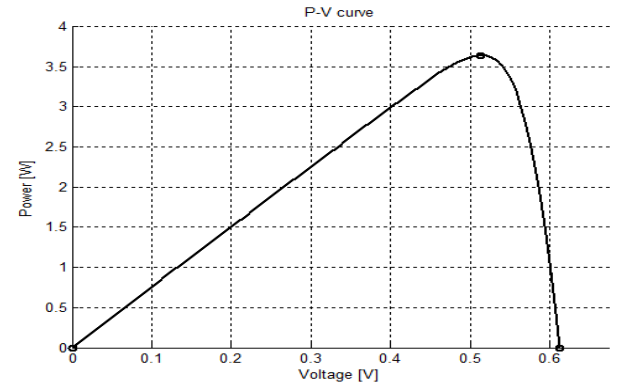

Figure 5.2: P-V characteristics of a solar cell

This plot gives the solar output power against the solar output voltage. This clearly abides by the theoretical plot that was shown previously. The maximum power point is marked with a small circle. The initial part of the plot from $0 \mathrm{~V}$ to the maximum power point voltage is a steady slope curve but after the maximum power point the curve is a steeply falling curve. 


\subsection{Simulation Results Of The Converter Model}

The simulations were carried out in Simulink and the various voltages, currents and power plots were obtained.

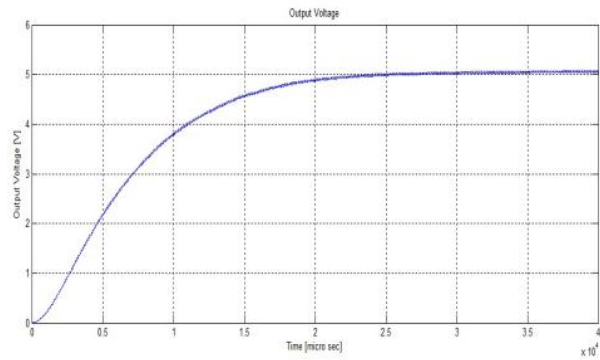

Figure 5.3: Output Voltage

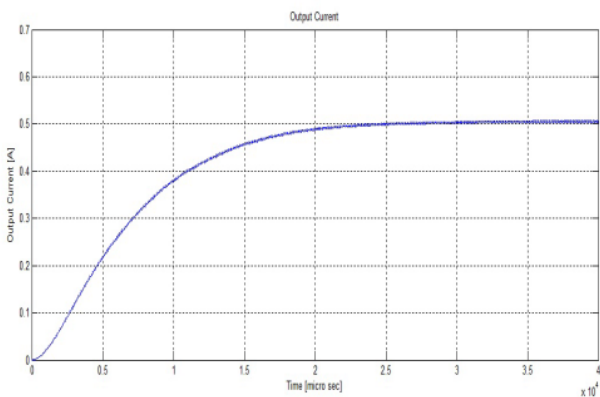

Figure 5.4: Output Current

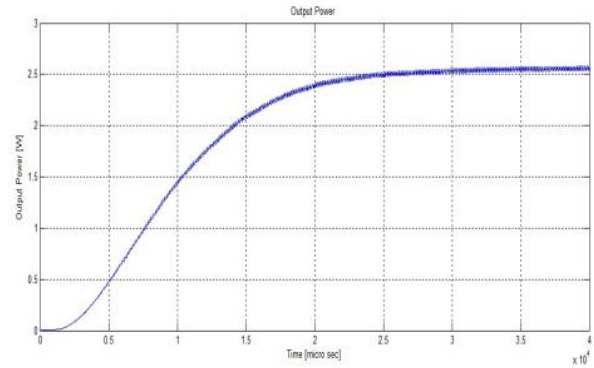

Figure 5.5: Output Power

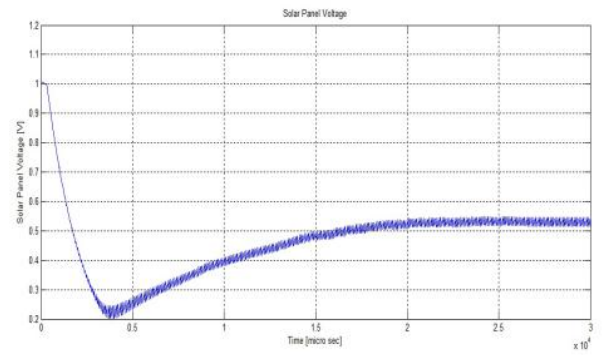

Figure 5.6: Solar Output Voltage

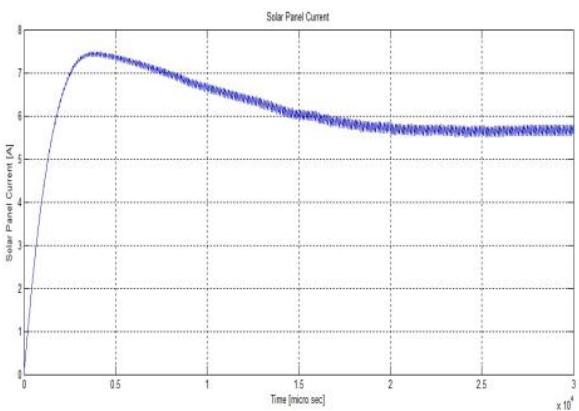

Figure 5.7: Solar Output Current 


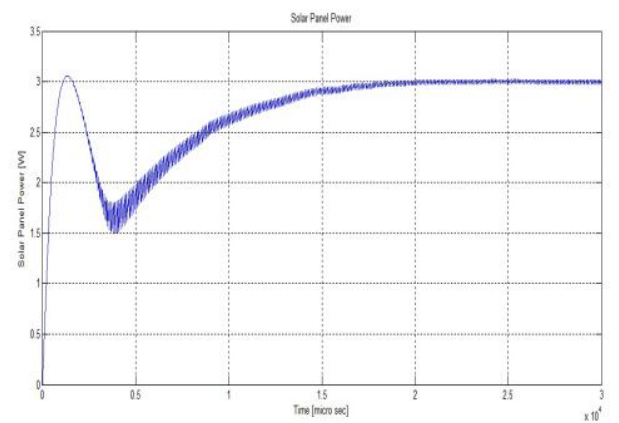

Figure 5.8: Solar Output Power

\section{Conclusion}

Various protection issues that arise when photovoltaic system is integrated in to the main grid are discussed and analyzed in this Paper. Technical challenges like power reversals change in fault current level of the network, possibility of sympathetic tripping, reduction in reach of distance relays, loss of relay coordination, unintentional islanding are briefly discussed. And simulation results are presented.

\section{Research scholar}

\section{Acknowledgements}

Puladasu Sudhakar born on $1^{\text {st }}$ January 1985 in polakal Kurnool (District) ,A.P ,India Obtained his B.Tech degree in 2006 and M.Tech degree in 2010 with a specialization in Power Systems with Emphasis on High voltage Engineering(PS-HVE), from JAWAHARLAL NEHRU TECHNOLOGICAL UNIVERSITY, presently he is a research scholar at JAWAHARLAL NEHRU TECHNOLOGICAL UNIVERSITY Anathapuramu and working as a Associate Professor at SSCET Kurnool he has 8 years of teaching experience ,his areas of research interests are power system protection and distributed generations.

\section{Supervisor}

Dr. M.Sushama, born on $8^{\text {th }}$ Feb 1973, in Nalgonda , a small town near Nagarjuna Sagar, A.P., India .Obtained her B.Tech degree in 1993 and M.Tech degree in 2003 with a specialization in Electrical Power Systems from JAWAHARLAL NEHRU TECHNOLOGICAL UNIVERSITY, INDIA. She obtained her Ph.D. from JNTU Hyderabad, India in 2009 in the area of "Power Quality" using Wavelet Transforms. She started her career as Assistant Professor in the Department of EEE, JNTU College of Engg., Anantapur, in the year 1995.. She worked as Associate Professor for $\mathbf{8}$ years in the Department of Electrical \& Electronics Engineering, JNTUH College Of Engg., Hyderabad. Presently she is working as Professor \& Head in Electrical \& Electronics Engineering in the Department of EEE, JNTUH College of Engineering, Kukatpally, Hyderabad. She had 18 years of teaching \& 7 years of research experience. She has published 17 international conference papers in various IEEE sponsored conferences, 15 International journal papers and one article in "Electrical INDIA". Her research interests include Power Quality, Wavelet Transforms, Neural \& Fuzzy expert Systems. She is currently guiding $5 \mathrm{Ph} . \mathrm{D}$ student. She is a life member of ISTE, Systems Society of India(SSI) \& IETE

\section{Co-supervisor}

Dr.B.Sarvesh Professor in Electrical and Electronics Engineering at JAWAHARLAL NEHRU TECHNOLOGICAL UNIVERSITY, INDIA. He has 32 years of teaching experience, 21 years of research experience he has published 01 national and 3 international journals he is also attended the one international and 7 national conferences he Served as Head of the EEE Dept., from 2002-2005 at JNTU CE, Kakinada, A.P, India from 2010-2012 at JNTUA CE, Anantapuramu. And he is also Served as Vice-Principal at JNTUA CE, Pulivendula A.P,India from 2007-2010. His research areas are control systems

\section{References}

[1]. 2008 National Electrical Code, ANSI/NFPA70, Published by the National Fire Protection Association, Quincy, MA, 2007.

[2]. King et al, "Performance Model for Grid-connected Photovoltaic Inverters," Sandia National Laboratories Report, SAND20075036, September 2007.

[3]. DOE Advanced Integrated Inverter and Energy Management - Technical Workshop Presentations, April 19, and May 10-11, 2007, Denver, CO and Santa Ana Pueblo, NM http://www2.eere.energy.gov/solar/solar_america/technology_pathway_partnerships_wks hp.html

[4]. Summary Report on the DOE High-tech Inverter Workshop, Jan, 2005,http://www1.eere.energy.gov/solar/pdfs/inverter_II_workshop.pdf 
[5]. Galvin Electricity Initiative, "The Path to Perfect Power - The Perfect Power System," 2007, http://www.galvinpower.org/galvinpower.pdf

[6]. 2005 NEC Handbook, NFPA70, Published by the National Fire Protection Association, Quincy, MA, 2005

[7]. Ton, D., Bulawka, A., Bower, W., Summary Report on the DOE Workshop On a Systems-driven Approach To Inverter Research and Development, U.S. Department of Energy, Solar Technology Program,http://www1.eere.energy.gov/solar/pdfs/sda_inverter.pdf Sep 2003.

[8]. Bower, W., Ropp, M., "Evaluation of Islanding Detection Methods for Photovoltaic Utility-interactive Power Systems", International Energy Agency Photovoltaic Power Systems Implementing Agreement, Task V; Grid Interconnection of Buildingintegrated and Other Dispersed Photovoltaic Power Systems, Report IEA PVPS T5-09: 2002, Feb. 2002.

[9]. Lee, F.C., Van Wyk, J.D., Boroyevich, D., Jahns, T., Lorenz, R.D., Chow, T.P., Gutmann, R.J., Barbosa, P., An Integrated Approach to Power Electronics Systems, Report for National Science Foundation, 2002.

[10]. UL Standard for Safety for Static Converters and Charge Controllers for Use in Photovoltaic Power Systems, UL1741, Underwriters Laboratories, Second Edition, Jan 2001.

[11]. IEC 61683, Photovoltaic systems - Power conditioners - Procedure for measuring efficiency, International Electrotechnical Commission, Pub. Nov 1999.

[12]. Beyond the "Balance of System - Growing Value of Solar Installations", Presented at Solar Power 2006, San Jose, CA, Sep 2006

[13]. ISET - Advancing Energy Systems, 2006 Annual Report, Institute for Solare Energieversorgungstechnik, Kassel, Germany

[14]. A. S. Sedra and K. C. Smith, Microelectronic Circuits. London, U.K.: Oxford Univ. Press, 2006.

[15]. H. J. M“oller, Semiconductors for Solar Cells. Norwood, MA: Artech House, 1993.

[16]. IEEE Standard Definitions of Terms for Solar Cells, 1969.

[17]. W. Xiao, W. G. Dunford, and A. Capel, "A novel modeling method for photovoltaic cells," in Proc. IEEE 35th Annu. Power Electron. Spec. Conf. (PESC), 2004, vol. 3, pp. 1950-1956.

[18]. Marcelo Gradella Villalva, Jonas Rafael Gazoli and Ernesto Ruppert Filho "Comprehensive Approach to Modeling and Simulation of Photovoltaic Arrays”, IEEE Transaction on Power Electronics, Vol. 24, No. 5, Pg.1198-1204, May 2009

[19]. C. Carrero, J.Amador, and S. Arnaltes, "A single procedure for helping PV designers to select silicon PV module and evaluate the loss resistances," Renewable Energy, vol. 32, no. 15, pp. 2579-2589, Dec. 2007.

[20]. Gwinyai Dzimano, B.S. "Modeling of Photovoltaic Systems", The Ohio State University, Pg.1- 18,48-52, 2008 